\title{
$11: 525550-522242$
}

National Cancer Institute

\section{Source}

National Cancer Institute. 11:525550-522242. NCI Thesaurus. Code C42491.

Physical location of HRAS_Gene 